\title{
Economic and environmental performances in manufacturing industries: A comparative study
}

\author{
Partha Pratim Sengupta ${ }^{1}$, Madhabendra Sinha ${ }^{1}$, Ujjjal Protim Dutta $^{1}$ \\ ${ }^{1}$ Department of Humanities and Social Sciences, National Institute of Technology Durgapur, West Bengal 713209, India
}

\section{Article Info}

Received Nov 10, 2018

\section{Keyword:}

Manufacturing

Production

Export

$\mathrm{CO}_{2}$ Emission

India and China

Time Series Econometrics

\begin{abstract}
The paper empirically investigates the dynamic relationships between economic and environmental performances in manufacturing industries on a comparative basis in India and China. The economic performance is generally measured by production and export. Manufacturing sector plays a crucial role in terms of GDP and export both in India and China due to existence of their emerging markets. The rapid export-led economic growth with remarkable contributions of manufacturing industries in India and China also raise the question of their environmental performances nowadays. In this context, environmental effect of manufacturing performances measured by the $\mathrm{CO}_{2}$ emission is a serious concern for both countries. The study is conducted within a causality framework by using World Bank data on Indian and Chinese economy from 1970 to 2016. Several unit root tests are conducted for all time series variables before applying the Johansen co-integration test followed by vector auto regression models to find their causal relationships. Findings show a unidirectional causal linkage between manufacturing production and $\mathrm{CO}_{2}$ emissions in both countries, the degree of the effect of manufacturing sector on $\mathrm{CO}_{2}$ emissions is remarkably higher in China than in India. Manufacturing export is also found as a significant factor in high level of $\mathrm{CO}_{2}$ emissions in China.
\end{abstract}

\section{Corresponding Author:}

Madhabendra Sinha,

Department of Humanities and Social Sciences,

National Institute of Technology Durgapur,

Durgapur, West Bengal 713209, India,

Email: madhabendras@gmail.com

\section{Introduction}

India and China had almost the same GDP per capita in 1990. The economy of China has been growing much faster than India and GDP per capita by its manufacturing sector on a purchasing power parity (PPP) basis is 90 percent higher than GDP per capita by manufacturing sector in India. India needs to strengthen its own manufacturing sector to achieve faster rates of economic growth. But most of the manufacturing production emits $\mathrm{CO}_{2}$. Tol (2005) concludes that emission of $\mathrm{CO}_{2}$ gas makes our world warmer. Climate change is complex, uncertain and the mother of all environmental problems. Greenhouse gases emitting sources are much more divided than all other environment related problems. Without emitting carbon dioxide no one can have energy at cheaper cost. Similarly, methane emissions require an important greenhouse gas for the construction of hydrogen in an anaerobic digestion and separation (Parker, 2000). Without emission of methane, no one have dairy items, mutton or rice. Thus, every organization, every farm, each family is responsible for emitting greenhouse gases.

Potentially green ideas are needed every day. Including public institutions, almost all organizations around 
the world, are looking for more innovative ways to increase their sustainability. Attention focused efforts to look at the emergence of renewable energy technologies and the adoption of green building ideas, solutions of sustainable waste management, sources of substitute energy and material, and the use of green growth increase. But as a whole this concept is neglected. As per World Bank data, $\mathrm{CO}_{2}$ emissions of India have increased by around 22 percent from 2007 to 2013 whereas in case of China the rate of increase in $\mathrm{CO}_{2}$ emissions was approximately 30 percent over the same period.

Both India and China have been the emerging suitable destinations for the investments of foreign capital by the Multi-National Enterprises (MNEs). In this context the pollution haven hypothesis (PHH) is one of the most important topics to be discussed in both countries. The PHH refers that heavy polluting industries will be relocated to the locations with feeble regulations of environment 'pollution havens' would be attracting the industries polluting more moving from places with more strict rules (Becker and Henderson, 2000). It is observed that MNEs shift investment preferences from developed to developing nations due to two reasons, those are low labour costs and relatively lax environmental regulations. In developing countries with cheap labour resources, there are less stringent restrictions on environment, and on the contrary, strict environmental restrictions become costly for firms due to the costs associated with meeting these standards. So, the firms that choose to invest physically abroad (again) are living in countries with less environmental standards or poor application.

Rothman (1998) found that the progress in the quality of the environment, in fact, can be a sign of the increased capacity of consumers in high-income countries to create a distance between themselves and the environmental degradation connected with their consumption. Hettige et al. (1992) observed that the rapid growth of toxic strength in high-profits nations at some points during the decade of 1960 and this trend became sharply opposite during the periods of 1970s and 1980s, following the advent of tougher guidelines of environment in OECD countries. Concurrently, toxic intensity in production in lower developed countries grew quickly. The study of Low and Yeats (1992) also confirmed the hypothesis of displacement.

Against this backdrop the paper examines the dynamic relationships on a comparative basis among the performances of manufacturing industries in terms of production, export, and $\mathrm{CO}_{2}$ emissions from manufacturing industries in India and china using the data from Word Development Indicators (2017) of World Bank from 1970 to 2016. The structure of this paper is divided as follows. Section 2 presents the Indian and Chinese scenarios of manufacturing industries and $\mathrm{CO}_{2}$ emissions with the existing evidences followed by the documentation of research hypotheses, data sources and methodological issues in section 3. Section 4 thoroughly analyses the empirical findings obtained from both India and china. Finally, section 5 presents the conclusion of the paper with observations derived from the comparative analysis.

\section{Manufacturing Sector and $\mathrm{Co}_{2}$ Emissions: Cases of China and India}

The world has been fast changing and the two new economic superpowers, China and India, are growing with their emerging market. In the world scenario, these two countries have emerged as leading actors. Until 1820, the Chinese economy was the largest economy in the world (The Globalist, 2014). During the recent past period, there have been so many discussions regarding the role of Indian and Chinese economies in the global economy on a comparative basis. The most important query from the sustainability perspective, is whether India or China will be emerging as the more dominant country? Also, how can these two emerging economies make a contribution to the Sustainable Development Goal? The three major essential areas are as follows: a) how can the Indian and Chinese economies support the sustainable development on their own? , b) how can these two countries work together? and c) how can their rapid growth in several ways contribute to the world sustainability in collaboration with the rest of the globe? Infrastructural investments are designed in both countries during the forthcoming years; however, they don't follow the unsustainable western development models (Carrasco et al., 2017). Strategies of global sustainability need assessing whether development trajectories of the nations have been sustainable over the period of time. Though, the evaluations of sustainability are limited due to the losses of natural capital and their ecosystem services. Both India and China are much relevant in this context where development strategies are not similar of that in western countries.

Over the next decade, it can be assumed that both India and China are becoming more powerful in economic sense, and the global economic focus will be gradually shifting from the currently dominating economies like European countries, Japan and USA to the India-China axis. The direction in which Indian and Chinese economies shift is, therefore, significantly influencing the world economic movements as a whole. Exports 
from China are not expensive and more attractive due to the low rate of wages and also lower cost of raw materials minimizing the costs of production. Furthermore, expensive pollution control policies are not usually implemented in Chinese economy. The rapid expansion of the economy of China with high consumption of coal has been a major source of emissions. Figure 1,2 and 3 show the comparative trends of $\mathrm{CO}_{2}$ emissions from manufacturing industries, and production and export of manufacturing industries respectively in India and china.

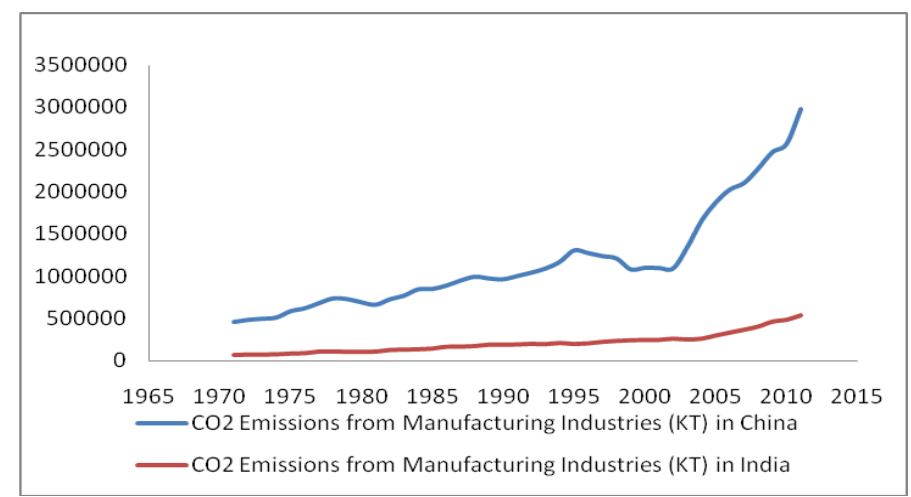

Figure 1. Trends $\mathrm{CO}_{2}$ Emission from Manufacturing Industries in India and China

Source: Annual Data from World Development Indicator 2017, World Bank

India-China comparative analyses on the above-mentioned issues are not well documented in the existing empirical studies as found so far. However, a few country-specific papers are reviewed carefully as follows. Weber et al. (2005) pointed out that approximately 33 percent $\mathrm{CO}_{2}$ emissions were sourced from productions of manufacturing commodities in China for export while Wang and Watson (2008) made a conclusion that net exports of China has accounted for around 23 percent of total $\mathrm{CO}_{2}$ emissions in the year 2004. The study of Shui and Harris (2003) observed that, almost 14 percent of $\mathrm{CO}_{2}$ emissions in China were coming from exports of the goods producing sectors. In the year 2012, the $\mathrm{CO}_{2}$ emissions in India continued to be increased by 6.8 percent with the total of 2.0 billion tones. As a result, India has become the fourth largest $\mathrm{CO}_{2}$ emitting nation. It should also be mentioned here that the two-third of total $\mathrm{CO}_{2}$ emission is the result of 10 percent increase in consumption of coal and 55 percent increase in the burning of fossil-fuel and production of electricity.

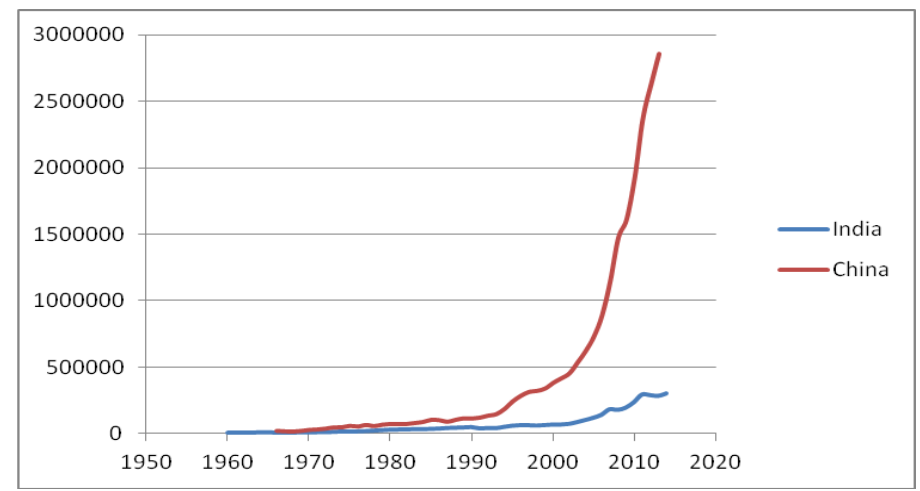

Figure 2. Trends of Production in Manufacturing Industries in India and China in US\$ Billion Source: Annual Data from World Development Indicator 2017, World Bank

Parikh and Gokarn (1993) attempted to estimate the levels of emissions in different sectors in India over the period of 1983-84 and their study offered another explanation of the idea of 'incremental costs', even if the comparison of two separate strategies of development. Mukhopadhyay and Forsell (2005) documented the trends of $\mathrm{SO}_{2}, \mathrm{CO}_{2}$, and other economic parameters for the periods of 1973-74 followed by 1983-84 and then 1991-92 and finally 1996-97 employing the input-output methods and observed some significant results. Nag and Parikh (2005) provided some significant empirical outcomes from the estimations with time series data on per unit indirect $\mathrm{CO}_{2}$ emissions from power consumption. Sharma et al. (2006) discussed the emissions of entire greenhouse gases in India due to agricultural activities, energy, forestry, industrial processes, land use and waste management practices for the years 1990, 1994 and 2000. 


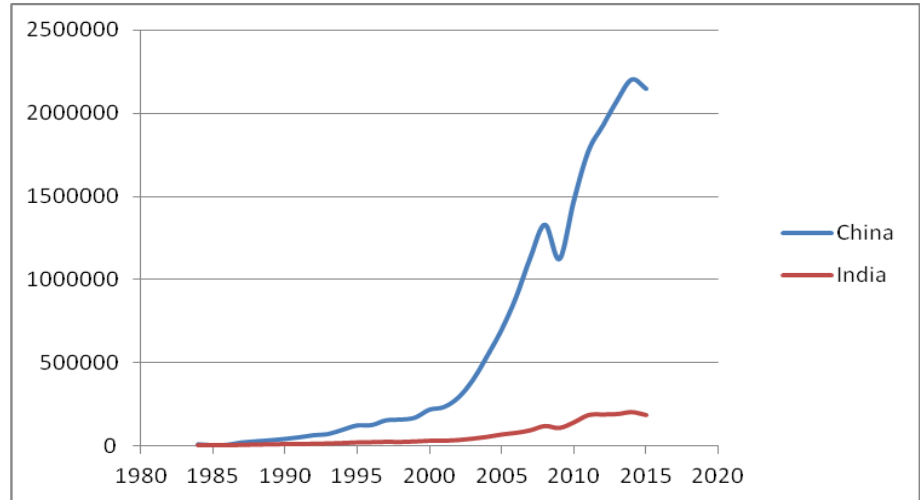

Figure 3. Trends of Manufacturing Exports from India and China in US\$ Billion Source: Annual Data from World Development Indicator 2017, World Bank

Firm level energy intensity of Indian manufacturing industries along with their determinants are empirically analysed by Sahu and Narayanan (2011) and Goldar (2015). Both the papers utilized the data on Indian manufacturing from PROWESS database of CMIE. However, their attempts to link the $\mathrm{CO}_{2}$ emission as a spin-off of heterogeneity across firms were not successful. In this context, the present study offers a comparative analysis on India and China to analyse their economic and environmental performances as per current need.

\section{Data and Methodology}

Based on the introductory background followed by the existing scenarios and evidences on the specific issues of the study as discussed earlier, two general null hypotheses have to be tested regarding the attainment of the objective of the study, in case of India and China, are categorized as follows:

(a) Manufacturing production does not cause the $\mathrm{CO}_{2}$ emission, and

(b) Manufacturing export does not have any effect on $\mathrm{CO}_{2}$ emission.

The data on manufacturing production, export and $\mathrm{CO}_{2}$ emissions per capita in metric tons are collected from the country wise data base of World Development Indicators (WDI) (2017) provided by World Bank over the period of 1970-2016, indicating that the study captures 47 observations for all considered variables for both the countries, India and China. We use different notations of the variables for India and China. $\mathrm{CO}_{2}$ emissions, manufacturing production and manufacturing export are denoted by CO2I, MANI and MEXI respectively in case of India. Similarly, for China the notations of the variables are CO2C, MANC and MEXC respectively. The existence of correlation across the observations is one of the significant characteristics of time series data. For instance, current year income of an individual is significantly correlated with the last year income. The study used Augmented Dickey-Fuller (ADF) (1979) as well as Phillips-Perron (PP) (1988) time series unit root tests to scrutinize the stationarity properties of time series data. The ADF (1979) test is presented in the following regression equation (1):

$$
\Delta X_{t}=\phi_{0}+\beta t+\rho X_{t-1}+\sum_{i=1}^{P} \gamma_{i} \Delta X_{t-1}+\varepsilon_{t}
$$

The intercept and trend components have been incorporated in the above equation. ADF (1979) test is grounded on the null hypothesis of non-stationarity (having unit root) against the alternative hypothesis of stationarity (no unit root) in the time series data. The PP (1988) test diverges from ADF unit root test mainly how it deals with the heteroskedasticity and serial correlation in the disturbance term. Both of these tests applied in the level as well as in the first difference of the time series variables. In addition to this, the study used Akaike (1969) Information Criterion (AIC) for selection of the optimal lag.

To investigate the conintegrating relationship amid the concerned variables, the study adopts the cointegration technique of Johansen and Juselius (1990). Johensen cointegration test is adopted to establish cointegrating relationships within variables. Johansen and Juselius (1990) laid down two likelihood ratio tests namely the Maximum Eigen value as well as the Trace statistics for identifying cointegrating vectors within time series 
variables. Both of these test statistics based on the assumption of no cointegration against the presence of cointegrating relationship as the alternative hypothesis.

After identifying the cointegrating relationship, the study adopted Vector Autoregressive Model (VAR). According to Engle and Granger (1987), if there is cointegration between two time series data, then it will lead to causal relation in at least one direction. Moreover, the VAR model is also illustrated in the Granger representation theorem. VAR model can be exemplified at levels and first difference both. In case of two variables, say $\mathrm{X}$ and $\mathrm{Y}$, the model of cointegration in the form of VAR framework can be illustrated in the following form of equations (2) and (3):

$$
\begin{aligned}
& \ln X_{t}=\theta+\sum_{i=1}^{p} \pi_{i} \ln X_{t-i}+\sum_{j=1}^{r} \phi_{j} \ln Y_{t-j}+v_{t} \\
& \ln Y_{t}=\alpha+\sum_{i=1}^{m} \beta_{i} \ln X_{t-i}+\sum_{j=1}^{n} \gamma_{j} \ln Y_{t-j}+u_{t}
\end{aligned}
$$

If the variables are not cointegrated, then we can investigate the short run dynamic relationships amongst them by using the unrestricted VAR structure expressed in the given equations (4) and (5).

$$
\begin{aligned}
& \Delta \ln X_{t}=\alpha_{0}+\alpha_{1} \Delta \ln X_{t-1}+\alpha_{2} \Delta \ln Y_{t-1}+\varepsilon_{1 t} \\
& \Delta \ln Y_{t}=\beta_{0}+\beta_{1} \Delta \ln X_{t-1}+\beta_{2} \Delta \ln Y_{t-1}+\varepsilon_{2 t}
\end{aligned}
$$

In the above equations, $\Delta X_{t}$ and $\Delta Y_{t}$ are used as explanatory variables, indicating the short term dynamic relationships in VAR structure. If the coefficient of $\Delta X_{t}$ is statistically significant in equation 5 then it implies that $\mathrm{X}$ effects $\mathrm{Y}$ and vice versa. If the coefficients of $\Delta X_{t}$ and $\Delta Y_{t}$ are not statistically significant, then it suggests that there is no causal relationship between the two series.

\section{Empirical Outcomes}

Using the empirical research methodology of the study suitable for the time series data as mentioned earlier, this section presents the outcomes of unit root tests followed by the cointegration tests and VAR model for both India and China separately.

\subsection{Findings from India}

\subsubsection{Unit Root Tests}

Table 1 presents the outcomes of ADF (1979) and PP (1988) time series unit root tests for all variables in case of India. It is observed that all the variables are suffered from the unit root problems at level. However, the first-differenced forms of the variables are free of unit roots as both ADP and PP unit root tests report.

Table 1. Outputs of Time Series Unit Root Tests for India

\begin{tabular}{ccccc}
\hline Series & \multicolumn{2}{c}{ ADF (1979) Test } & \multicolumn{2}{c}{ PP (1988) Test } \\
\cline { 2 - 5 } CO2I & Level & First Difference & Level & First Difference \\
MANI & 3.13 & $-7.59 * * *$ & -2.09 & $-7.59 * * *$ \\
MEXI & -1.65 & $-4.90^{* *}$ & -1.71 & $-4.91 * *$ \\
Note: $* *$ and $* * *$ indicate $5 \%$ and $1 \%$ significance levels respectively & $-6.99 * * *$ \\
\hline
\end{tabular}

Source: Own estimations of authors using World Bank (2017) data for India

To explore the dynamic linkages among CO2I, MANI and MEXI, the Engle and Granger (1987) proposed cointegration method can be employed as unit root test statistics imply that series are found to be integrated of order one i.e. I(1), signifying that they may have a common trend in character as it has been observed that all variables follow same order of integration, then the study can opt for cointegration test.

\subsubsection{Cointegration Test}

The estimated outcomes of the Johansen cointegration tests are presented in Table 2. Both the trace-statistic and maximum eigenvalue test statistic are followed to express the results of testing of the null hypothesis of 
the presence of cointegrating relationships among variables in contradiction of the alternative hypothesis of full rank. Findings do not include any cointegrating equation at 5 percent level.

Table 2: Outputs of Cointegration Test for India

\begin{tabular}{cccccc}
\hline Tests & $\begin{array}{c}\text { Hypothesized } \\
\text { No. of CE(s) }\end{array}$ & Eigenvalue & Statistic & $\begin{array}{c}\text { 5\% Critical } \\
\text { Value }\end{array}$ & Prob.** \\
\hline Trace & None & 0.256555 & 21.12144 & 29.79707 & 0.2251 \\
& At most 1 & 0.206392 & 13.89136 & 15.49471 & 0.1506 \\
& At most 2 & 0.113734 & 2.79543 & 3.841466 & 0.2161 \\
Maximum & None & 0.256555 & 14.23009 & 21.13162 & 0.3465 \\
Eigenvalue & At most 1 & 0.206392 & 11.09593 & 14.26406 & 0.1495 \\
\multicolumn{7}{l}{ Trace and Max-eigenvalue tests indicate no cointegration equation(s) (CE(s)) at 5\% level } \\
**Probability (p)-values of MacKinnon-Haug-Michelis (1999) \\
\hline
\end{tabular}

Source: Own estimations of authors using World Bank (2017) data for India

In absence of the cointegrating relationship, the short run dynamics among those variables can be verified by using the unrestricted VAR framework after incorporating the two-period lags as prescribed by the minimum AIC criteria. Table 3 shows the projected outcomes of the unrestricted VAR models. All figures in brackets ([]) point out the corresponding t statistics of the coefficients.

Table 3. Estimated Coefficients in Unrestricted VAR for India

\begin{tabular}{cccc}
\hline & $\mathrm{D}(\mathrm{CO} 2 \mathrm{I})$ & $\mathrm{D}(\mathrm{MANI})$ & $\mathrm{D}(\mathrm{MEXI})$ \\
\hline $\mathrm{D}(\mathrm{CO} 2 \mathrm{I}(-1))$ & -0.677604 & 0.107454 & -1.217342 \\
& {$[-2.98642]$} & {$[0.31108]$} & {$[-1.48145]$} \\
$\mathrm{D}(\mathrm{CO} 2 \mathrm{I}(-2))$ & -0.39494 & 0.03073 & -0.395151 \\
& {$[-2.44982]$} & {$[0.34332]$} & {$[-0.55198]$} \\
$\mathrm{D}($ MANI (-1)) & 0.213305 & -0.215037 & 0.338056 \\
& {$[1.98940]$} & {$[-1.18748]$} & {$[0.23341]$} \\
$\mathrm{D}($ MANI (-2)) & 0.162653 & 0.130901 & 1.17242 \\
& {$[2.23425]$} & {$[0.74088]$} & {$[0.82968]$} \\
$\mathrm{D}($ MEXI (-1)) & 0.074281 & -0.000473 & 0.056518 \\
& {$[1.37404]$} & {$[-0.01575]$} & {$[0.23543]$} \\
$\mathrm{D}($ MEXI (-2)) & 0.049528 & 0.00992 & 0.015062 \\
& {$[1.36229]$} & {$[0.49144]$} & {$[0.09329]$} \\
$\mathrm{C}$ & 0.003051 & 0.001007 & -0.000229 \\
& {$[0.50684]$} & {$[0.30139]$} & {$[-0.00856]$} \\
$\mathrm{R}^{2}$ & 0.494631 & 0.418842 & 0.391153 \\
Adjusted R & 0.382562 & 0.283628 & 0.331642 \\
F-statistic & 3.712612 & 0.795018 & 5.267499 \\
Log likelihood & 89.13378 & 97.3769 & 17.57580 \\
Akaike (AIC) & -2.380574 & -2.437319 & -0.398992 \\
Schwarz (SC) & -2.042507 & -2.219505 & -0.087125 \\
\hline Source: Own estimations of authors using World Bank (2017) data for India
\end{tabular}

The results of three separate VAR equations using three different lag variables are expressed in Table 3. One of those implies that MANI significantly influences CO2I with both one and two periods' lags.

\subsection{Findings from China}

\subsubsection{Unit Root Test}

Similar types of results of ADF (1979) as well as PP (1988) time series unit root tests on variables for China are presented in Table 4 . The observed findings are also same kinds of findings in case of India, indicating 
that all the variables namely $\mathrm{CO} 2 \mathrm{C}, \mathrm{MANC}$ and MEXC are non-stationary at level but they become unit root free at their first differences.

Table 4. Outputs of Time Series Unit Root Tests for China

\begin{tabular}{|c|c|c|c|c|}
\hline \multirow[t]{2}{*}{ Series } & \multicolumn{2}{|c|}{ ADF (1979) Test } & \multicolumn{2}{|c|}{ PP (1988) Test } \\
\hline & Level & First Difference & Level & First Difference \\
\hline $\mathrm{CO} 2 \mathrm{C}$ & 0.07 & $-3.41 * *$ & -0.33 & $-4.87 * * *$ \\
\hline MANC & 0.41 & $-5.51 * * *$ & 0.27 & $-5.51 * * *$ \\
\hline MEXC & -0.08 & $-4.41 * * *$ & -0.13 & $-3.52 * *$ \\
\hline
\end{tabular}

Source: Own estimations of authors using World Bank (2017) data for China

For the Chinese economy, unit root test outcomes imply that all of the variables follow same order of integration (order one, i.e. I(1)). So, usually, the cointegration test is supposed to be applied to explore the possible cointegrating relationships among variables as they may have a common trend.

\subsubsection{Cointegration Test}

Table 5 contains the estimated findings of Johansen cointegration tests for the case of China. Like the results of Indian economy, here also no significant cointegrating equation is observed among three variables as per reports of both trace and maximum Eigen value statistic at 5\% level. These results insist us to apply VAR models again in case of China like India.

Table 5. Outputs of Cointegration Test for China

\begin{tabular}{cccccc}
\hline Tests & $\begin{array}{c}\text { Hypothesized } \\
\text { No. of CE(s) }\end{array}$ & Eigenvalue & Statistic & $\begin{array}{c}\text { 5\% Critical } \\
\text { Value }\end{array}$ & Prob.** \\
\hline Trace & None & 0.328741 & 27.24919 & 29.79707 & 0.0957 \\
& At most 1 & 0.168498 & 8.913589 & 15.49471 & 0.3734 \\
Maximum & At most 2 & 0.009210 & 0.425602 & 3.841466 & 0.5142 \\
Eigenvalue & None & 0.328741 & 18.33561 & 21.13162 & 0.1178 \\
\multicolumn{7}{c}{ At most 1 } & 0.168498 & 8.487987 & 14.26460 & 0.3312 \\
Trace and Max-eigenvalue tests indicate no cointegration equation(s) (CE(s)) at 5\% level \\
**Probability (p)-values of MacKinnon-Haug-Michelis (1999) \\
\hline
\end{tabular}

Source: Own estimations of authors using World Bank (2017) data for China

To look at the short run dynamic relationships among variables, the unobstructed VAR framework including the two periods' lags as per AIC suggestions is utilized here. The VAR results using three different variables with lags are presented in Table 6 simultaneously.

Table 6. Estimated Coefficients in Unrestricted VAR for China

\begin{tabular}{cccc}
\hline & $\mathrm{D}(\mathrm{CO} 2 \mathrm{C})$ & $\mathrm{D}(\mathrm{MANC})$ & $\mathrm{D}(\mathrm{MEXC})$ \\
\hline $\mathrm{D}(\mathrm{CO} 2 \mathrm{C}(-1))$ & -0.16061 & -1.20292 & -2.45577 \\
& {$[10.9724]$} & {$[0.80829]$} & {$[0.17067]$} \\
$\mathrm{D}(\mathrm{CO} 2 \mathrm{C}(-2))$ & -0.81552 & -1.22888 & -0.6054 \\
& {$[-4.59402]$} & {$[-0.92428]$} & {$[-0.22304]$} \\
$\mathrm{D}($ MANC $(-1))$ & -0.02482 & 1.103738 & -0.06688 \\
& {$[-1.37935]$} & {$[8.19136]$} & {$[-0.24312]$} \\
$\mathrm{D}($ MANC $(-2))$ & 0.017304 & -0.31075 & 0.049478 \\
& {$[0.96187]$} & {$[-2.30635]$} & {$[0.17988]$} \\
$\mathrm{D}($ MEXC $(-1))$ & -0.02286 & -0.04087 & 1.286281 \\
& {$[-2.05638]$} & {$[-0.49093]$} & {$[7.56900]$} \\
$\mathrm{D}($ MEXC $(-2))$ & 0.030714 & 0.015343 & -0.30288 \\
& {$[2.49418]$} & {$[0.16636]$} & {$[-1.60859]$} \\
$\mathrm{C}$ & 0.320407 & 7.889791 & 1.550967 \\
\hline
\end{tabular}




\begin{tabular}{cccc}
\hline & {$[1.16811]$} & {$[3.84044]$} & {$[0.36980]$} \\
$\mathrm{R}^{2}$ & 0.695331 & 0.794621 & 0.663434 \\
Adjusted $\mathrm{R}^{2}$ & 0.594613 & 0.678407 & 0.657808 \\
F-statistic & 85.63800 & 55.18142 & 71.25850 \\
Log likelihood & 30.40742 & -62.2151 & -95.04481 \\
Akaike (AIC) & -1.01771 & 3.009353 & 4.436729 \\
Schwarz (SC) & -0.73944 & 3.287624 & 4.715001 \\
\hline Source: Own estimations of authors using World Bank (2017) data for China
\end{tabular}

The same patterns of results are also observed in case of Chinese manufacturing sector, where the manufacturing productions significantly influence the level of $\mathrm{CO}_{2}$ emissions. Additionally VAR model shows that manufacturing export with one period lag is also a significant factor of high level of $\mathrm{CO}_{2}$ emissions in China, which has not been found in case of India.

\section{Conclusion}

Emissions of $\mathrm{CO}_{2}$ have increased exponentially over the years due to the phenomenon of industrialization, resulting in an overall degrading effect on the environment. In developing countries, this poses a more serious problem than the developed countries as the environmental rules are not so strictly implemented and regulated in the developing countries. For these countries, growth of the economy is much more important as they face a lot of other social issues like unemployment, population explosion, etc. They, therefore, tend to overlook the environmental conditions and the negative impact that the economic growth efforts might have on the environment. The present empirical exercise for the last forty-seven years, spanning over the period of 1970 to 2016, has focused on the effects of $\mathrm{CO}_{2}$ emission on manufacturing industries and exports and imports. This paper has looked at the effects of $\mathrm{CO}_{2}$ emissions released due to energy consumption for rapid economic growth leading to environmental degradation in India and China. This study differs from the others as we have tried to see the rate of $\mathrm{CO}_{2}$ emissions in case of India and China (i.e., which country produces more $\mathrm{CO}_{2}$ to produce the same quantity of same goods). The results suggest that energy consumption is essential for growth and development which has an effect on the emissions of $\mathrm{CO}_{2}$ in all the countries, which we have tried to examine by focusing on India and China in this study. This excessive consumption of energy resources by both the countries is fueled by industrialization, economic growth, international trade including Import and exports.

The paper has endeavored to lend a new dimension to the various approaches to the study of environmental management and economic performance in manufacturing industries in India and China through the research undertaken for this study. To strike the right balance between environment and industrial growth is very difficult to achieve yet it is the need of the hour now. It has been seen that the industrialization process has acted as a catalyst to growth but in the process, it has led to imbalances in the environment. Given the ill effects of extensive energy consumption, it is extremely tough to cut down the energy consumption levels because of its negative impact on the development of the economy, more so, in cases of the fast-emerging economies like India and China which are highly dependent on energy usage. The larger energy consuming nations should look at ways to cut down the rate at which they are consuming energy resources; and if this is left unchecked, it will inevitably lead to environmental imbalances in the future.

Economic growth of any developing country is intrinsically related to the industry and manufacturing sector of that country. This means that the country would have to rely heavily on the consumption of energy resources. This heavy and unchecked consumption of resources in turn has detrimental effect on the environment of the country due to the emissions of harmful gases like $\mathrm{CO}_{2}$. The developing countries are aware of the negative consequences of the rapid expansion of industries yet they sometimes have to overlook these issues as there are other pressing concerns which precede this in importance for them. Growth is their need of the hour and so they sometimes compromise with the quality of environment to negotiate with the need for development. There is a direct link between the expansion of industry and the effect that it has on the environment.

We should look at environmental efficiency as well as energy efficiency to attain the desired maximum output while keeping in mind that we should reduce per unit environmental damage done to achieve economic gain. Practically speaking, it is impossible to visualize a world now where we can survive without the comforts of the modern world which has been made possible by the technological advancements and things produced 
which involves energy resources. In this situation, what we can do is to strive for efficient use of energy in all sectors as global warming; climatic changes and depletion of resources are a reality which can no longer be ignored. Beyond the purview of this study, there is further scope of investigating this area of research by focusing on the various aspects of sustained relationship and studying the complex relationship between consumption of energy, growth of the economy and industrialization in India and China. This would guarantee more significant results and important analysis which could be valuable for the policymakers and researchers involved in this area of study in both these countries to formulate policy plans and strategies with a view to maintain a sustainable environment as well as to stimulate growth and development by striking the perfect balance.

Numerous commentators are strongly in favour of India following China's footsteps. While growth changes to lessen the poverty ratio of India from 45.3 million in 1993-1994 to 22 million in 2011-12, it lacks dynamism inside the transformation to a current economic system: most of the people of its staff should be shifted from agricultural to non-agricultural activities. India should deliver a speedy increase in -intensive depth production for a faster transformation (Panagariya, 2008). In case of India, the 2011 "national manufacturing coverage" goals to generate one hundred million employment inside the manufacturing phase by way of 2022 and a 25 percent enhancement GDP production/ manufacturing from the current 18 percent. Organising "national investment production Zones" along with China's "big monetary zones" coverage is a prime manner of accomplishing this intention. At the same time as there is a comparative analysis of the manufacturing sectors of India and China, it argues that despite the fact that there are lots in commonplace between the two nations, the policy framework of China and the blessing of development and boom may not be India's function model. Demographic characteristics, historic policy background and mainly political configuration all are very notably amid the two countries. Apparently, each nation is stricken by those disparities in the sort of coverage choices.

Two very different development paths have been introduced by China and India. Each has leveraged its strength in the development of its individual manufacturing Sectors. In China, the development of its manufacturing sector has been truly prosperous, but the services sector has been very short. In the services sector, however, India was extremely successful, but its manufacturing sector has fallen short. Therefore, in India, China seeks lessons learned and vice versa. India needs to improve its infrastructure, develop human capital and offer some preferential treatment in order to increase the FDIs and encourage specific industrial development in order to further develop its manufacturing sector. As a result, India has to develop a Special Economic Zone like China to enable high infrastructure facilities and manufacturing abet. Due to Chinese experience, the continuing growth of the manufacturing sector requires higher foreign direct investment (FDI) levels. However, India's FDI regulation would find it difficult to liberalize while Some Indian government groups oppose multinational investment. China must seek expansion beyond its boundaries as software technology is intrinsically a global business. China should further endeavor, through industrial internationalization, to end violations of "intellectual property rights". Continued growth requires less intervention from government and more entrepreneurship as protected industries are not competing in the global environment.

Besides it, although a trade organization is crucial in guaranteeing a better system of regulation, it can be more difficult for this recommendation to be implemented in China because the Chinese administration does not allow non-governmental organizations. Hence, in China, a NASCOM is therefore not possible. In general, India and China have productive comparisons of success factors in specific industries. Furthermore, both the rates of production as well as the growth of productivity in India were quite modest compared to that of China. More sustainable growth is mainly attributed to an increase in productivity. The Indian situation shows a sharp increase in productivity, but the low or negative growth rate showed respectively between 1983-93 and 1993-99. Although, China's growth was higher and its manufacturing industry productivity was also impressive but, the sustainability of the growth process, as well as the arguments of lower returns, and the availability of factor inputs have been raised from the environmental perspective.

\section{Acknowledgements}

Authors are thankful to the organizers and participants of the ICCMIT'19 held at Vienna, Austria during 2628 March 2019, where the initial version of this paper was presented. Reviewer's comments are gratefully acknowledged. Useful disclaimers apply. 


\section{References}

[1] Akaike, H. (1969). Fitting autoregressive models for prediction. Annals of the Institute of Statistical Mathematics, 21, 243-247.

[2] Becker, R., \& Henderson, V. (2000). Effects of air quality regulations on polluting industries. Journal of Political Economy, 108(2), 379-421.

[3] Carrasco, L. R., Le Nghiem, T. P., Chen, Z., \& Barbier, E. B. (2017). Unsustainable development pathways caused by tropical deforestation. Science advances, 3(7), 1-9.

[4] Dickey, D. A., \& Fuller, W. A. (1979). Distribution of the estimators for autoregressive time series with a unit root. Journal of the American statistical association, 74(366a), 427-431.

[5] Engle, R. F., \& Granger, C. W. (1987). Co-integration and error correction: representation, estimation, and testing. Econometrica, 55(2), 251-276.

[6] Globalist, The. (2014). Twelve (12) Facts on China's Economic History. Washington DC: The Globalist.

[7] Goldar, B. (2015). Productivity in Indian manufacturing (1999-2011): accounting for imported materials input. Economic and Political Weekly, 50(35), 104-111.

[8] Granger, C. (1981). Some Properties of Time Series Data and Their Use in Econometric Model Specification. Journal of Econometrics. 16(1), 121-130.

[9] Hettige, H., Lucas, R. E., \& Wheeler, D. (1992). The toxic intensity of industrial production: global patterns, trends, and trade policy. The American Economic Review, 82, 478-481.

[10] Johansen, S., \& Juselius, K. (1990). Maximum likelihood estimation and inference on cointegration with applications to the demand for money. Oxford Bulletin of Economics and statistics, 52(2), 169-210.

[11] Low, P., \& Yeats, A. (1992). Do 'Dirty' Industries Migrate? In P. Low (edn.), International Trade and environment, Washington DC: World Bank.

[12] MacKinnon, J. G., Haug, A. A., \& Michelis, L. (1999). Numerical distribution functions of likelihood ratio tests for cointegration. Journal of applied Econometrics, 14(5), 563-577.

[13] Mukhopadhyay, K., \& Forssell, O. (2005). An empirical investigation of air pollution from fossil fuel combustion and its impact on health in India during 1973-1974 to 1996-1997. Ecological Economics, 55(2), 235-250.

[14] Nag, B., \& Parikh, J. K. (2005). Carbon emission coefficient of power consumption in India: baseline determination from the demand side. Energy Policy, 33(6), 777-786.

[15] Panagariya, A. (2008). What India Must Do to Modernize. Vox. Available at http://www. voxeu. org/article/why-india-lags-behind-china. Accessed September, 4, 2013.

[16] Parikh, J., \& Gokarn, S. (1993). Climate change and India's energy policy options: new perspectives on sectoral CO2 emissions and incremental costs. Global Environmental Change, 3(3), 276-291.

[17] Parker, P. M. (2000). Physioeconomics - The Basis for Long-Run Economic Growth. Cambridge, MA: MIT Press.

[18] Phillips, P. C., \& Perron, P. (1988). Testing for a unit root in time series regression. Biometrika, 75(2), 335-346.

[19] Rothman, D. S. (1998). Environmental Kuznets curves-real progress or passing the buck?: A case for consumption-based approaches. Ecological economics, 25(2), 177-194.

[20] Sahu, S. K., \& Narayanan, K. (2011). Total factor productivity and energy intensity in Indian manufacturing: A cross-sectional study. International Journal of Energy Economics and Policy, 1(2), 4758.

[21] Sharma, S., Bhattacharya, S., \& Garg, A. (2006). Greenhouse gas emissions from India: A perspective. Current Science-Bangalore, 90(3), 326.

[22] Shui, B., \& Harriss, R. C. (2006). The role of CO2 embodiment in US-China trade. Energy policy, 34(18), 4063-4068.

[23] Tol, R. S. J. (2005). The marginal damage costs of carbon dioxide emissions: an assessment of the uncertainties. Energy Policy, 33(16), 2064-2074.

[24] Wang, T., \& Watson, J. (2008). China's carbon emissions and international trade: implications for post2012 policy. Climate policy, 8(6), 577-587.

[25] Weber, C. L., Peters, G. P., Guan, D., \& Hubacek, K. (2008). The contribution of Chinese exports to climate change. Energy Policy, 36(9), 3572-3577.

[26] World Bank (2017). World Development Indicators. Washington DC: World Bank. 